\title{
DEVELOPING E-AUTHENTICATION FOR E-ASSESSMENT - DIVERSITY OF STUDENTS TESTING THE SYSTEM IN HIGHER EDUCATION
}

\author{
Sanna Uotinen [sanna.uotinen@jyu.fi], Tarja Ladonlahti [tarja.ladonlahti@jyu.fi], Merja \\ Laamanen [merja.h.laamanen@jyu.fi], University of Jyväskylä, Finland
}

\begin{abstract}
E-authentication is one of the key topics in the field of online education and e-assessment. This study was aimed at investigating the user experiences of students with special educational needs and disabilities (SEND) while developing the accessible e-authentication system for higher education institutions. Altogether, 15 students tested the system (including instruments for face recognition, voice recognition, keystroke dynamics, text style analysis and anti-plagiarism), developed as part of the TeSLA project. Students also completed pre-questionnaires and postquestionnaires and attended individual interviews. The findings reveal positive expectations and experiences of e-authentication. Students believed that the e-authentication system increased trust and, thus, diversified their possibilities for studying online. Students found some challenges and emphasized that the e-authentication system should be reliable and easy to use. The possibility to use different kinds of instruments was perceived as an important feature. Students' willingness to use these instruments and share their personal data for e-authentication varied due to their disabilities or individual preferences. The results suggest that students should have options for what kind of e-authentication they use.
\end{abstract}

\section{Abstract in Finnish}

Sähköinen tunnistautuminen on yksi keskeisistä teemoista verkko-opetuksessa, -opiskelussa ja arvioinnissa. Tämän tutkimuksen tarkoituksena oli tutkia opiskeluunsa erityistä tukea tarvitsevien yliopisto-opiskelijoiden käyttökokemuksia kehitteillä olevasta sähköisestä tunnistautumisjärjestelmästä. Erityistä huomiota kehittämistyössä kiinnitettiin tunnistautumisen saavutettavuuteen. Kaikkiaan 15 opiskelijaa testasi TeSLA-projektin osana kehitettyä tunnistautumisjärjestelmää, johon kuului kasvojentunnistus, äänentunnistus, näppäilyntunnistus, tekstityylianalyysi ja plagioinnin tunnistus. Opiskelijat täyttivät esi- ja jälkikyselylomakkeet sekä osallistuivat henkilökohtaisiin haastatteluihin. Tulokset osoittivat, että opiskelijoilla oli positiivisia odotuksia ja kokemuksia sähköisestä tunnistautumisesta. Opiskelijat uskoivat, että tunnistautumisjärjestelmä lisäsi luottamusta ja siten monipuolisti heidän mahdollisuuksiaan opiskella verkossa. Opiskelijat löysivät joitain haasteita ja korostivat, että sähköisen tunnistautumisjärjestelmän tulisi olla luotettava ja helppokäyttöinen. Mahdollisuutta käyttää erilaisia tunnistautumisvälineitä pidettiin tärkeänä. Opiskelijoiden halu käyttää näitä välineitä ja jakaa henkilötietojaan tunnistautumiseen vaihteli vammaisuuden, tuen tarpeiden tai yksilöllisten mieltymysten mukaan. Tulokset viittaavat siihen, että opiskelijoilla pitäisi olla vaihtoehtoja siihen, millaista sähköistä tunnistautumista he käyttävät. 
Keywords: e-authentication, e-assessment, special educational needs and disabilities (SEND), higher education, accessibility, TeSLA system

\section{Introduction}

Integration of information and communication technologies (ICT) in academic studies is a reality at all higher education institutions (Heiman et al., 2017). Online programmes and courses have become a customary part of higher education practices. Some universities are fully online, and traditional universities are increasingly offering blended and online education courses. E- assessment systems follow the same development.

Online education provides new options for students with Special Educational Needs and Disabilities (SEND) to participate, and thus improves their access to higher education (Coleman \& Berge, 2018). European Disability Strategy 2010-2020 highlights the goal of promoting inclusive education and lifelong learning for people with disabilities (European Commission, 2010). It is known that diversity of students as well as the number of higher education students with SEND is growing (Snyder et al., 2018). In Finland, the results of a national survey of higher education students revealed that $8.2 \%$ of students have a learning difficulty, illness or disability that affects their learning (Kunttu et al., 2017). While looking at special educational needs of students in larger context, the number is even higher. According to Eurostudent survey, 28\% of Finnish higher education students had chronic illness, mental health problems, physical restriction, sensory disability, learning difficulty (ADHD, dyslexia), other long-term health problem, physical restriction or disability (Potila et al., 2017). 70\% of those students informed that this hampered their studying.

It is also likely that the proportion of students with disabilities in higher education is undervalued and the number is larger than reported (Grimes et al, 2017). For various reasons, students do not always want to disclose disabilities, even if doing so would enable them to receive better support (Grimes et al., 2017; Kent et al., 2018). In Verdinelli and Kutner's (2016) study, students experienced discrimination due to their disability in the traditional education environment, but in the online environment, they did not endure stigmatization or stereotypical treatment. In addition, participants experienced a greater sense of control and academic efficacy when studying online (Verdinelli \& Kutner, 2016). Thus, teachers instruct diverse students enrolled in higher education courses without knowing their special educational needs (Lombardi et al., 2015). In the context of online education, recognizing students' special educational needs can be even more difficult than in traditional campus education. Therefore, accessibility must be a self-evident part of the online course design, not something to address after a student has disclosed a disability (Betts et al., 2013; Ladonlahti et al., 2020).

Accessibility means that "people with disabilities have access, on an equal basis with others, to the physical environment, transportation, information and communications technologies and systems (ICT) and other facilities and services" (European Commission 2010; p.5). Directive (EU) $2016 / 2102$ is aimed at ensuring that all websites and mobile applications of public sector bodies are accessible, so that everyone can access and understand the meaning of the content (EUR-lex, 2019). 
Inclusive and accessible online learning requires an approach that addresses both technology and pedagogy (Kent et al., 2018). Access to education should always mean that, for example, course contents, learning activities and all services that students need are accessible (Betts et al. 2013). If online education is created in an accessible way, this will open up more possibilities for all students to study (see Macy et al., 2018).

\section{The need for student authentication and authorship verification in online education}

Although online education offers many benefits, like new ways of representing knowledge and increased flexibility of studying (Timmis et al., 2016), it also raises new issues to consider. Amigud (2013) reminds us that new technologies may facilitate cheating. In addition, in Mellar et al.'s (2018) study, teachers expected cheating to become a greater problem with the increased use of eassessment. Many higher education instructors saw an effective e-authentication system as a prerequisite for the larger use of e-assessment (Mellar et al., 2018). Researchers and higher education staff have acknowledged the need for reliable ways to confirm students' identities. There is a need to develop systems for student authentication and authorship verification. At the same time, it is important to ensure that the systems are accessible for a diversity of students as well as those using assistive technology (e.g. Amigud, 2013; Mellar et al., 2018).

Username and password identification are often used to control access to the online learning environment, but this is an inadequate approach to authentication (Amigud, 2013). Some systems also deploy biometric technologies (Amigud, 2013; Lee-Post \& Hapke, 2017). Lee-Post and Hapke (2017) argue that biometric-based authentication solutions require the use of special devices. In addition, concerns have been raised about data security and privacy issues in dealing with sensitive user data (Lee-Post \& Hapke, 2017).

However, universities seem to enjoy the status of trustworthy operators. Levy et al. (2011) indicate that students taking online courses are more willing to share their biometric data with the university than with a private vendor offering the same service. Guillén-Gámez et al. (2015) recommend the gradual introduction of biometric authentication systems for students online. Students who used biometric authentication in their study were more favourable to, and comfortable with, it and appreciated the implementation of this technology compared to those students who had not tested the software. In Okada, Noguera, et al.'s (2019) study, teaching staff believed that the e-authentication system would increase students' awareness of cheating and plagiarism. However, they also believed that it would not be possible to prevent fraud totally. In Okada, Whitelock, et al.'s (2019) study, e-authentication for online assessments was received rather positively by students. E-authentication should offer more possibilities for assessment, for example with the flexibility of time or place to study. Nevertheless, students with disabilities, on average, had various concerns and relatively negative attitudes towards e-authentication due to their lack of confidence and concerns about their limitations (Okada, Whitelock, et al., 2019). It appears that students with SEND do not find e-authentication completely suitable for them and their needs are not sufficiently recognized. This underlines the importance of SEND students' role as partners when developing e-authentication system for e-assessment. 


\section{E-authentication system to verify authentication and authorship online}

Developing and testing the system for verifying students' authentication and authorship in a digital learning environment (DLE) was the main focus of the TeSLA project (Adaptive Trust-Based eAssessment System for Learning). The TeSLA project (Horizon 2020) involved 18 partners: eight universities, three quality agencies, four research centres and three technological companies. The project was committed to accessibility - that is, students with SEND were included as potential users of the TeSLA system. The developed system was tested at seven pilot universities in 20162018 (TeSLA, 2019).

During the project, five different authentication and authorship verification instruments were integrated into the system (Table 1): face recognition, voice recognition and keystroke dynamics for biometric authentication and plagiarism detection and forensic analysis for authorship verification (Knuth, 2016).

Table 1. Instruments integrated in the TeSLA system

\begin{tabular}{|c|c|}
\hline TeSLA instrument & Description \\
\hline Face recognition & $\begin{array}{l}\text { Instrument analyses visual data, such as images or videos. It compares the } \\
\text { characteristics of a student shown on video against the characteristics of the } \\
\text { student stored in a database. There must be a camera connected to the } \\
\text { computer. }\end{array}$ \\
\hline Voice recognition & $\begin{array}{l}\text { Instrument verifies a student's identity by comparing the characteristics of } \\
\text { the voice with a model derived from examples of speech during enrolment. } \\
\text { To record audio signals, a microphone must be connected to the computer. }\end{array}$ \\
\hline Keystroke dynamics & $\begin{array}{l}\text { Instrument recognizes patterns based on the timing information from } \\
\text { pressed and released keys when a student is typing on a keyboard. }\end{array}$ \\
\hline Anti-plagiarism & $\begin{array}{l}\text { Instrument detects word-for-word copies in a given document by comparing } \\
\text { it to all other documents. }\end{array}$ \\
\hline Forensic analysis & $\begin{array}{l}\text { Instrument verifies that a document has been written by a specific author. } \\
\text { There must be a set of text files written by the author. }\end{array}$ \\
\hline
\end{tabular}

All instruments, except plagiarism, required at least two samples from each student to allow for comparing the samples. TeSLA system has been designed for use with commonly available devices like ordinary laptop; therefore, students do not have to supply any special devices (see Mellar et al., 2018; TeSLA, 2019). TeSLA system does not require any special software or hardware. It is integrated to the learning management system. Students need a microphone for voice recognition, a web camera for face recognition and a keyboard for keystroke dynamics. The system is also easy to use. The user does not need any specific education to be able to use it. All the instructions are included in the system.

\section{Research questions and methods}

This study was carried out to investigate user experiences of students with SEND, who tested an eauthentication system (face recognition, voice recognition, keystroke dynamics and forensic analysis), and their perceptions of e-authentication in higher education studies. Plagiarism detection was not part of this study. 
The research questions were as follows:

- What kind of user experiences do students with SEND have of the e-authentication system?

- What are the benefits and challenges of the e-authentication system according to higher education students with SEND?

\section{Participants}

Participants of this study came only from one TeSLA pilot university. Altogether, 15 university students (eleven female, four male) participated in the study. They ranged in age from 20 to 48 years, with most of them having been born in the 1990s. They were undergraduate students in a Finnish university from the faculties of humanities and social sciences, education and psychology, mathematics and science. All participants had special educational needs. The classification of students with special educational needs and disabilities for the research were built together with other pilot universities. According to the information that participants shared, nine of them had reading and writing difficulties or some other specific learning difficulty, two of them were partially sighted, one student had chronic illness, one student had problems with attention and concentration, and two students were deaf and used sign language.

Students participated voluntarily. Each student received 10 vouchers for lunch at the student canteen after completing the testing and the interview. In addition, they participated in a lottery to win one of two iPads with all other students who took part in the TeSLA study.

\section{Data collection}

University's accessibility planning coordinator sent an invitation email to all students with SEND at the university. Those students who decided to volunteer sent an email to the researchers and provided their contact information. After that, researches sent more information (e.g. video recording) explaining about the TeSLA project and about the study to the volunteered students.

Students took part in structured, face-to-face tests of the system. The testing was conducted between December 2017 and May 2018 and occurred on the university premises. At the time of data collection, the TeSLA system was still in development. Each test scenario included questionnaires and a face-to-face interview at the end of the session. Before the testing and interview, all students provided informed consent, which presented data protection and privacy information about TeSLA project and the present study. Digital consent form included detailed information about what kind of authentication and authorship verification instruments students are asked to use, what kind of data is gathered, where it will be stored, and how it will be used. Participants accepted the digital consent form by marking a cross. Researches also confirmed participants' agreement orally, and made sure that test situation can be videotaped, and data can be used for research. The researchers emphasized that students were free to drop out of the study at any time. Students were also able to ask the researchers about the study and pose questions about anything that was unclear. Students tested face recognition, voice recognition, keystroke dynamics and forensic analysis, and the whole test took two-to-three hours per student. The time spent for 
all these steps varied a lot, depending mainly on the participants' speed of reading, speed of typing, personal characteristics of speech and voice.

All participants were asked to follow the same steps for the system test (Figure 1). Students logged in with their username and password and accessed the TeSLA Moodle environment.

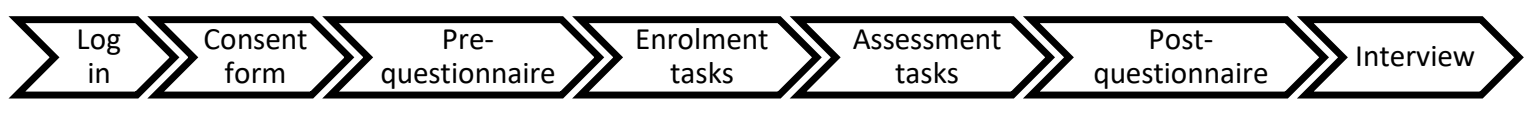

Figure 1. Students' steps for testing the system

They accepted the consent form, which confirmed their participation in the TeSLA project and the present study. Subsequently, they completed the pre-questionnaire. Then students were asked to complete the enrolment activities to initialise (set a baseline for) the system. This involved typing 250 words, providing voice samples and videos of the face and sharing text documents. Next, students performed assessment tasks that involved typing answers to some simple questions, reading answers aloud, keeping the camera on and sharing text documents (Table 2). At the end, students completed a post-questionnaire about their experience of the TeSLA system.

Table 2: TeSLA instruments' enrolment and assessment tasks for the participants

\begin{tabular}{lll}
\hline TeSLA instrument & Enrolment tasks & Assessment tasks \\
\hline Face recognition & Videorecorded face & Keep the web camera on \\
Voice recognition & Utter voice samples & Read answers out load \\
Keystroke dynamics & Type 250 words & Type answers to questions \\
Forensic analysis & Share text documents & Share text documents \\
\hline
\end{tabular}

After completing these steps, students were interviewed. This study was mainly based on the interview data. The aim of the interviews was to obtain feedback on the TeSLA system and instruments and gain knowledge of the experiences and expectations of the e-authentication system. All participants were interviewed individually, but the number of researchers in the test situation varied. To build and ensure a common structure for the test situation, three researchers interviewed the first two students. The rest of the interviews were completed by two researchers, with two exceptions when only one researcher was available. The two students using sign language had an interpreter involved in their interviews. Interviews lasted from 7 minutes to 22 minutes. Interviews were conducted in Finnish; thus, all quotations in the Findings section were translated from Finnish to English by the authors. Each student was assigned an individual number and abbreviation, such as S1. Three dots (...) denote that a quotation was condensed.

Furthermore, minor parts of the participants' $(\mathrm{N}=15)$ pre-questionnaire and post-questionnaire data were used. One multiple choice question from the pre-questionnaire and three multiple choice questions from the post-questionnaire data were included in this study to add some extra information about the themes that emerged from the interviews. Students were asked in both questionnaires which types of personal data they were willing to share in the e-authentication process. In the post-questionnaire, students were asked about the main advantages and 
disadvantages of e-assessment for students. Students also had the opportunity to comment freely on the advantages and disadvantages of e-assessment.

\section{Analysis}

Interviews were audio recorded and the recordings were transcribed verbatim. In total, 70 pages of transcribed text (12-point font size) were gathered from the interviews. The transcribed data were analysed qualitatively using content analysis (Patton, 2015; p.541). The analysis process was inductive, and the unit of analysis was unity of one thought or meaning. The length of this unity was usually a sentence or at least a few words. Qualitative data analysis software Atlas.ti was used at the beginning of the analysis to organize the data.

Both investigator triangulation and data triangulation were used (Patton, 2015, p. 316). Only one researcher conducted the analysis but discussed the categories closely with the other researchers; therefore, all authors were involved. The main data were derived from the interviews, whereas the questionnaire data were used to verify and identify possibly inconsistent contents, meaning that data triangulation was used to a lesser degree.

\section{Findings}

\section{Experiences of the TeSLA e-authentication system}

Willingness to share personal data

All participants had opportunities to test all instruments, including sharing voice, video of their face and written text, and typing. One student with hearing impairment declined to do the voice recognition, but all other participants attempted to use all instruments. Generally, they felt quite comfortable with sharing their personal data for authentication and had positive perceptions of the different ways of sharing data.

In the pre-questionnaire (before testing) and post-questionnaire (after testing), students were asked which types of personal data they were willing to share in the e-authentication process. The question was not directed to any specific situation, but into student's study context in general. When answering the post-questionnaire all students had the experience of using TeSLA e-authentication instruments. In Table 3, the plus sign (+) stands for a student's willingness to share information and the minus sign (-) stands for a student's unwillingness to share. The situations before and after testing are separated with a slash (before/after). Students were more willing to share text-based information than biometric data, including picture or audio data (Table 3). 
Table 3: Students' $(\mathrm{N}=15)$ willingness to share information about themselves before and after testing the e-authentication system

\begin{tabular}{|c|c|c|c|c|c|c|}
\hline \multirow[b]{2}{*}{ Student description } & \multicolumn{6}{|c|}{$\begin{array}{l}\text { Type of information and student's willingness to share it before/after testing (+ } \\
\text { means positive, - means negative) }\end{array}$} \\
\hline & $\begin{array}{l}\text { Writing for } \\
\text { checking } \\
\text { plagiarism }\end{array}$ & $\begin{array}{l}\text { Writing for } \\
\text { analysing } \\
\text { style of } \\
\text { writing }\end{array}$ & $\begin{array}{l}\text { Still photo } \\
\text { of face }\end{array}$ & $\begin{array}{l}\text { Audio } \\
\text { recording } \\
\text { of voice }\end{array}$ & $\begin{array}{l}\text { Video of } \\
\text { face }\end{array}$ & $\begin{array}{c}\text { Keyboard } \\
\text { dynamic } \\
\text { (persona } \\
\text { typing } \\
\text { rhythm) }\end{array}$ \\
\hline $\begin{array}{l}\text { Student using sign } \\
\text { language }\end{array}$ & $+/+$ & $+/+$ & $+/+$ & $-/-$ & $-/-$ & $-/-$ \\
\hline $\begin{array}{l}\text { Student using sign } \\
\text { language }\end{array}$ & $+/+$ & $+/+$ & $+/+$ & $+/+$ & $+/+$ & $+/+$ \\
\hline $\begin{array}{l}\text { Student with reading } \\
\text { and writing difficulties }\end{array}$ & $+/+$ & $-/+$ & $+/+$ & $+/+$ & $-/+$ & $+/+$ \\
\hline $\begin{array}{l}\text { Student with reading } \\
\text { and writing difficulties }\end{array}$ & $+/+$ & $+/+$ & $+/+$ & $+/+$ & $+/+$ & $+/+$ \\
\hline $\begin{array}{l}\text { Student with reading } \\
\text { and writing difficulties }\end{array}$ & $+/+$ & $+/+$ & $-/-$ & $-/-$ & $-/-$ & $+/+$ \\
\hline $\begin{array}{l}\text { Student with some } \\
\text { physical challenges and } \\
\text { slow speech }\end{array}$ & $+/+$ & $+/+$ & $+/-$ & $-/+$ & $-/-$ & $-/-$ \\
\hline $\begin{array}{l}\text { Student with some } \\
\text { learning difficulties }\end{array}$ & $+/+$ & $-/-$ & $+/+$ & $+/-$ & $-/-$ & $-/-$ \\
\hline $\begin{array}{l}\text { Student with reading } \\
\text { and writing difficulties } \\
\text { and some other } \\
\text { learning difficulties }\end{array}$ & $+/+$ & $+/+$ & $-/-$ & $-/-$ & $-/-$ & $+/+$ \\
\hline $\begin{array}{l}\text { Student with some } \\
\text { learning difficulties, } \\
\text { perception difficulties } \\
\text { and panic disorder }\end{array}$ & $+/+$ & $+/+$ & $-/-$ & $-/+$ & $-/-$ & $+/+$ \\
\hline $\begin{array}{l}\text { Student with reading } \\
\text { and writing difficulties }\end{array}$ & $+/+$ & $+/+$ & $-/-$ & $-/+$ & $-/-$ & $+/+$ \\
\hline Student with ADHD & $+/+$ & $-/-$ & $-/-$ & $-/+$ & $-/-$ & $+/+$ \\
\hline $\begin{array}{l}\text { Student with reading } \\
\text { and writing difficulties } \\
\text { and perception } \\
\text { difficulties }\end{array}$ & $+/+$ & $+/+$ & $+/+$ & $-/-$ & $-/-$ & $+/+$ \\
\hline $\begin{array}{l}\text { Student with limited } \\
\text { vision }\end{array}$ & $+/+$ & $+/+$ & $+/-$ & $+/+$ & $-/-$ & $+/+$ \\
\hline $\begin{array}{l}\text { Student with limited } \\
\text { vision }\end{array}$ & $+/+$ & $+/+$ & $+/+$ & $-/-$ & $-/-$ & $+/+$ \\
\hline $\begin{array}{l}\text { Student with reading } \\
\text { and writing difficulties } \\
\text { Positive views from all }\end{array}$ & $+/+$ & $+/+$ & $+/+$ & $-/+$ & $-/+$ & $-/+$ \\
\hline $\begin{array}{l}15 \text { students } \\
\text { (before/after) }\end{array}$ & $15 / 15$ & $12 / 13$ & $10 / 8$ & $5 / 9$ & $2 / 4$ & $11 / 12$ \\
\hline
\end{tabular}

The questionnaire data showed that there were no big differences in students' willingness to share information about themselves before and after the testing. Seven out of 15 participants did not change their attitudes at all. In all, students were slightly more willing to share information about themselves after the testing than before the testing. Five out of 15 students developed more positive attitudes towards the instruments, with the audio recording of the voice demonstrating the most 
dramatic positive change. Finally, after testing, 5 out of 15 students were willing to share all personal data for which they were asked. Only the request to share a still photograph of the face and audio recording of the voice were responded to with less willingness by some students after testing (Table 3).

Similar answers were given in the interviews and questionnaires. Some students experienced sharing biometric data as unpleasant. There were more doubts about sharing video of the face or voice than about typing. Students were unaccustomed to sharing video for identification; thus, doing so gave them an uncomfortable feeling. One student stated, "It [face recognition] was somehow annoying because it is something that I am not used to doing. In addition, I think it is maybe a bit intrusive. Usually, it is [identity] numbers and something like that, which you give online, but this is maybe too sensitive because there is the face picture" (S8). One student pondered that someone might have a camera phobia and a video would not be pleasant. However, a student with hearing impairment said that she was so attuned to using the camera with her friends that she had no problem with sharing a video of her face.

Moreover, upon seeing her face on the screen, one participant began to feel uncertain. Thus, showing one's face was experienced uncomfortable, and reading aloud into a microphone was strange for some students. One student mentioned, "if you have to read or speak out load or show your own face, so those felt quite strange (...)" (S12). Another student said, "Maybe giving the voice sample was a bit weird or felt the most unfamiliar. Otherwise, everything was okay" (S15). One student with hearing impairment stated that she did not want to do the voice recognition. Her first language was sign language and she was not used to using her voice. The other student with hearing impairment confirmed that deaf students seldom want to use their voice, and in this kind of recognition system, one should always have an option for this. However, he was willing to provide the voice recording: "(...) because I was born with hearing and later on, I lost it, so I am able to use my voice" (S2).

It was mainly the video of the face and voice recording which aroused doubts, but for some students, typing was awkward as well. A student with learning difficulties mentioned that writing was difficult for her; therefore, speaking or using video for recognition were easier for her. In addition, a student who used sign language had doubts about writing: "It [typing] is challenging. (...) I think the uncertainty is because of the Finnish language. At least for me, when I must write, I feel insecure. (...) If I could just use sign language, it would be more natural” (S1). However, participants described sharing typing samples and written text samples for identification in a rather neutral way.

\section{Ease of use of the system}

Many students expressed overall positivity towards the TeSLA system. Students acknowledged that it was interesting, and they perceived it as the current way and part of modern daily life. "It was quite fun. I haven't done anything like this before, so it was nice" (S4). "Well, it was new and special" (S6). In addition, some students thought that it was no big deal and stated that they had 
used similar kinds of systems before. Some students described the use of TeSLA as "smooth", "simple" or "easy".

There was also some hesitation towards the TeSLA system. Owing to the newness of such an authentication system to most participants, they needed time to get used to it. One interviewee was considering TeSLA for other students, and she pointed out, "I think some of the students will experience this as strange - having to share picture and voice and all” (S15). Students mentioned that at first, there might be some doubts and suspicions regarding the new technology.

Some students described the screen layout as unclear and stated that it was time-consuming to find the right way to proceed. “But I don't - maybe you noticed that I didn't perceive right away where to get it and where I should go. I don't know if others can perceive it; is this general or is it just me?” (S11). Another student stated, “(...) Maybe it is because of my dyslexia that it was really difficult for me to piece together what is relevant here" (S4). An authentication system should be user-friendly and direct every user automatically.

Participants perceived the ability to use different kinds of authentication instruments as an important factor. They were pleased that students had various possibilities for carrying out authentication. "I think, I have a good feeling about all of this. It [TeSLA] is versatile. It is not just one but there is lots of different information, like voice, video and typing. It was nice" (S3). The possibility to use different authentication instruments was important also because of students' disabilities. Participants emphasized that the user should be able to decide which instrument is appropriate for them. “(...) But if a person is deaf from birth, they necessarily won't want to use voice and, therefore, neither voice recognition, but if there are options for you to use just, for example, two instruments, then there is no problem. But if you must use all four instruments, then it is a barrier" (S2). Thus, a requirement to use all instruments was considered a problem.

\section{Technical characteristics of the system}

The technical reliability of the TeSLA system was mentioned as an essential element. It was seen as important that the technique itself be assured so that the student does not have to worry about using it. One student pointed out the following: "One must develop a guaranteed system where everything works" (S9). During the test situation, some technical difficulties occurred for some students, and these affected their experiences. Students wanted to be sure that when they have, for example, an exam, e-authentication does not complicate participation.

Some instruments demanded several samples, which participants experienced as quite burdensome. Some main concerns were related to voice recognition, which required several voice samples recorded at the enrolment phase. "But the voice sample was hard; you had to work for a surprisingly long time for your voice (...)" (S12). To share voice samples, students could freely say whatever they wanted to or could read a text aloud. In both cases, the TeSLA system informed the user when the number of samples was sufficient. One reason why this instrument required a lot work was that the voice samples needed to be continuous with no long pauses. It is typical for Finnish speakers to have some pauses while speaking. Furthermore, if one has difficulties in speaking or a slow pace of talking, voice recognition is challenging. 
Technical aspects of the TeSLA system received praise and, overall, the system was perceived as simple to use. In addition, participants made more specific observations. For example, a student with visual impairment pointed out that the keyboard shortcut buttons, which helped the user move around the screen, functioned well.

\section{Benefits and challenges of e-authentication according to students with SEND}

\section{More alternative ways to study}

The main advantage of e-authentication was the increased possibilities for online education, and this gives students more freedom to decide for themselves how and where to study. The interviewed students were mainly participating in face-to-face courses at the university, and they believed that e-authentication would enable more flexibility and new online education modes. The possibility of taking exams or listening to lectures at home was viewed very favourably. "It would make it possibly to do that stuff at home; you are not so dependent on the particular place” (S4). A student with visual impairment mentioned his preference for writing exams at home: "If you have a disability, you want to have more control over the situation" (S13). It was also seen as important when a student has a special situation, such as if the student is sick or is on a trip/vacation. In addition, online education would make it possible to continue to study during an internship. All students in the questionnaire agreed that one of the benefits of e-assessment was being able to determine a time or place for taking an exam.

However, some students emphasized that the option for face-to-face studying should remain. These students did not want to study strictly online. They wanted to meet their instructors one-on-one and liked studying in the university buildings. In the questionnaire, one student clarified that a disadvantage of e-assessment is that teacher-student contact might cease.

\section{Increased trust in studying}

Students stated that the e-authentication system might increase confidence both in students and teachers: "Perhaps it would create security on both sides" (S4). It was argued that it would foster trust in teachers towards students; for example, the teacher can be sure that it is the right person doing the exam and not someone else.

Students' increased safety and trust were important benefits of e-authentication. Interviewees stated that it is to the students' benefit if they are better recognized because this increases safety and individuality. For a student, it is also important to know that no outsider can utilize a student's exams or assignments: "It increases every student's right to their own writings and assessments, and it makes it possible to recognize the student better, so it is like a protection (...) and my work is mine - nobody can snatch or use it" (S9).

\section{Students' own challenges}

Students had issues concerning their own ICT skills. Some students were uncertain about whether they could manage the e-authentication system by themselves. One student mentioned that her ICT skills were poor. She thought she would be nervous if she had to perform e-authentication at home before she could start to study. A student with reading and writing problems stated that it 
requires too much effort for her to first concentrate on e-authentication and then, only after that, to start studying: "(...) It is hard for me to concentrate on the main thing if, all the time, I am aware that I am being videotaped or I must give voice samples or something like that. It will produce extra tension and studying itself might become more difficult" (S12). One student also assumed that because of her learning difficulties, she had difficulties with technical activities and often needed help.

When studying online, the possibility to save money and time was highlighted by the students. On one hand, being able to study at home would decrease the driving back and forth to the university, and this was an advantage. On the other hand, financial issues bothered some students. Eauthentication requires certain kinds of technical equipment and students questioned if everyone would have adequate equipment. In the questionnaire, 12 students expressed that they should have some extra technological equipment and eight students stated that they would need time to learn a new technology.

\section{Issues with security}

Some interviewees pondered issues relating to security and data protection in the internet. The opinions were mixed. Students who did not have doubts about security and data protection said that they were used to sharing information about themselves. They had good trust in their security.

Students who had doubts about security did not focus so much on the system that they were testing as on the internet overall. One student was sceptical about privacy and data protection and was critical about these issues at the university. "The more I read about data protection, the more suspicious I am about how the data can be protected" (S6). Students were aware that the internet has lots of information about them and this knowledge did not always feel good. In the questionnaire, one student commented that possible security breach or information misuse are disadvantages of e-assessment.

\section{Discussion}

A qualitative study design was used to investigate aspects of accessible e-authentication in higher education. The focus of the study was on the perceptions of students with SEND testing the TeSLA e-authentication system. Thus, the study was intended to shed light on students' experiences of testing the system as well as their opinions about the benefits and challenges of using the eauthentication. The main results of the study are discussed as follows.

When describing their perceptions of e-authentication, students focused relatively little on their own disabilities or special educational needs and, instead, brought up more general issues. Aspects relating to the students themselves focused mainly on possibilities and skills to study. Students believed that the e-authentication system would increase their possibilities for pursuing online education, and they were pleased about this. They saw online education as a positive development, which allows more flexible and individualized ways to study. As in previous studies, online education was experienced as beneficial by students with SEND (Kent et al., 2018; Verdinelli \& Kutner, 2016). 
Furthermore, financial issues were connected to e-authentication in the study. Online education was perceived as economical because, for example, it reduces traveling. However, students acknowledged that e-authentication would require a certain amount of ICT equipment. Awareness of what kind of equipment is needed is important, and students should be informed by the university about this. As new innovations in technology emerge, it is also important to ensure that all students have equal opportunities to participate. While new technology is beneficial for many students, it may also be unavailable to some students (Coleman \& Berge, 2018). To avoid these issues The TeSLA system was designed for reliance on the use of commonly available devices (see Mellar et al., 2018).

Another important aspect of this study was trust. Currently students confront questions of digital trust in many ways. It is not just the study context, but many parts of student's life are in digital environments and these bring out new questions and challenges for security and trust. First, students argued that an e-authentication system would increase mutual trust between students and teachers. In addition, students were content to know that third parties could not gain access to their papers. As there are doubts concerning cheating and plagiarism in online education, a reliable authentication system confirms the position of online education (Amigud, 2013). Second, trust was an important issue in data protection and security, which worried some students. As Levi et al. (2011) note, the home university has an important role in implementing a new system for students, especially when the system involves the sharing of biometric data.

Students perceived the possibility to use different kinds of authentication instruments as important. Some instruments are simply impossible for students with certain characteristics to use. In terms of preferences, students shared several reasons why they favoured a certain instrument. However, teachers are often unaware of such reasons why students struggle with, or cannot use, such systems. Even if the teacher is aware of a student's disability, the type of disability does not offer information about what kind of challenges this particular student has (Griful-Freixnet et al., 2017). Therefore, as part of the e-authentication system, it is essential to establish a process for obtaining students' viewpoints and the reality of their experience. When possible, the eauthentication system should offer students the possibility to determine themselves the best authentication approach. An individualized approach was recommended also in another study where students with different types of disabilities assessed the potential of the TeSLA system (Peytcheva-Forsyth et al., 2017).

Regarding e-authentication, its technical reliability is a significant element, which must be assured. If the aim is for e-authentication to be performed independently, the system must be reliable enough so that it does not complicate a studying. Overall, it is important that an e-authentication system is easy for everyone to use. Students should be able to perform e-authentication without strain or tension. Students' fear of undertaking it on their own is understandable. When studying online the teacher should ensure that students are not left alone but can ask for guidance if needed. There are many opportunities for student-teacher interaction online (e.g. Chou et al., 2010) and it has been acknowledged that this interaction is valuable for students in many ways (e.g. Baker, 2010; Fedynich et al., 2015). 
Besides technical reliability, accessibility issues must be managed when developing an authentication system, such as ensuring adequate colour contrast, a clear font and alternative text for images (Macy et al., 2018). These features are beneficial for all students, but they are necessary for students with SEND (Betts et al., 2013; Macy et al., 2018). Equally important is that the overall layout of the e-authentication system and the DLE are understandable and self-directed.

In general, students were quite comfortable with, and willing to, share their personal data for eauthentication. This result differs from Okada, Whitelock, et al.'s (2019) quantitative study, where students with disabilities had various concerns towards e-authentication. However, as the results show, it is difficult to predict what kind of personal data students are willing to share. The results of this qualitative study suggest that students' views on the e-authentication instruments varied and each student had individual preferences for certain instruments.

\section{Limitations and future research}

In the present qualitative study, the sample size $(\mathrm{N}=15)$ was rather small. Students, who expressed some interest in the study area to begin with, volunteered to participate. Therefore, students with highly critical views on e-authentication may not have participated in this study. The data from some interviewees was quite limited. At the same time, the relatively short interviews yielded important information about specific student experiences. The use of questionnaire data and consistent results with the interview data also confirmed the findings.

The data were gathered from students in a test situation, which must be considered when evaluating the results. During the test, students had access to help and support. The situation would be different if students were using the e-authentication system by themselves. In addition, the TeSLA e-authentication system was still in development during the data collection period and some technical problems occurred. Nevertheless, it is important to study user experiences when a system is still under development. Only by testing the system individually is it possible to determine its weak spots in terms of accessibility.

Overall, this study raises questions about how an e-authentication system works in practice when it is a regular part of online education. Future research should continue to focus on user/student experiences and determining what kind of information and help students need and the possible challenges that they may face.

\section{Conclusion}

Students' e-authentication in e-assessment and online education is a current issue for higher education institutions. Reliable e-authentication presumably assures the status of online education, and this opens up possibilities for many people to study. This study contributes to the existing research by shedding light on the experiences of students with SEND of testing an eauthentication system. Students had positive expectations of e-authentication. However, the findings raise issues for higher education staff to consider. It is worth noting that when integrating an e-assessment system in DLE, higher education institution must be aware of accessibility issues. Not all e-authentication instruments are easy to use or accessible for every student. The strength of 
TeSLA system was that it included different e-authentication instruments, thus, offering alternatives for students.

When possible, students could determine the most comfortable and suitable approach for them. Otherwise, e-authentication itself may be a new barrier. There can be two kinds of barriers. First, if the system does not work or is too difficult to use, it can create a technical barrier. Second, a psychological barrier may exist if using the system is unpleasant or arouses suspicion. Although the assumption is that e-authentication is performed individually, higher education staff should establish channels where students can ask for support if needed.

\section{References}

1. Amigud, A. (2013). Institutional level identity control strategies in the distance education environment: a survey of administrative staff. The International Review of Research in Open and Distributed Learning, 14(5). https://doi.org/10.19173/irrodl.v14i5.1541

2. Baker, C. (2010). The impact of instructor immediacy and presence for online student affective learning, cognition, and motivation. The Journal of Educators Online, 7(1). Retrieved from https://www.thejeo.com/archive/archive/2010_71/bakerpaperpdf

3. Betts, K., Cohen, A. H., Veit, D. P., Alphin, H. C., Broadus, C., \& Allen, D. (2013). Strategies to increase online student success for students with disabilities. Journal of Asynchronous Learning Networks, 17(3), 49-64.

4. Chou, C., Peng, H., \& Chang, C. (2010). The technical framework of interactive functions for course-management systems: students' perceptions, uses, and evaluations. Computers \& Education, 55(3), 1004-1017. Retrieved from https://www.learntechlib.org/p/66863/

5. Coleman, M., \& Berge, Z. L. (2018). A review of accessibility in online higher education. Online Journal of Distance Learning Administration, 21(1). Retrieved from https://www.westga.edu/ distance/ojdla/spring211/coleman_berge211.html

6. EUR-lex. (2019). Directive (EU) 2016/2102. Retrieved from https://eurlex.europa.eu/eli/dir/2016/2102/oj

7. European Commission. (2010). Communication from the Commission to European Parliament, the Council, the European Economic and Social Committee and the Committee of the Regions. European Disability Strategy 2010-2020: A Renewed Commitment to a Barrier-Free Europe. Retrieved from https://eurlex.europa.eu/LexUriServ/LexUriServ.do?uri=COM:2010:0636:FIN:en:PDF

8. Fedynich, L., Bradley, K. S., \& Bradley, J. (2015). Graduate students' perceptions of online learning. Research in Higher Education Journal, 27. Retrieved from https://files.eric.ed.gov/fulltext/EJ1056187.pdf

9. Griful-Freixenet, J., Struyven, K. Verstichele, M., \& Andries, C. (2017). Higher education students with disabilities speaking out: perceived barriers and opportunities of the universal 
design for learning framework. Disability \& Society, 32(10), 1627-1649. doi:10.1080/09687599.2017.1365695

10. Grimes, S., Scevak, J., Southgate, E., \& Buchanan, R. (2017). Non-disclosing students with disabilities or learning challenges: characteristics and size of a hidden population. Australian Educational Researcher, 44(4-5), 425-441.

11. Guillén-Gámez, F. D., Garcia-Magarino, I., \& Romero, S. J. (2015). Analysis of the perceptions of students about biometric identification. International Journal of Web-Based Learning and teaching Technologies, 10(3), 1-18. doi:10.4018/ijwltt.2015070101

12. Heiman, T., Fichten, C. S., Olenik-Shemesh, D., Keshet, N. S., \& Jorgenson. M. (2017). Access and perceived ICT usability among students with disabilities attending higher education institutions. Journal Education and Information Technologies, 22(6), 2727-2740.

13. Kent, M., Ellis, K., \& Giles, M. (2018). Students with disabilities and eLearning in Australia: experiences of accessibility and disclosure at Curtin University. TechTrends, 62(6), 654-663. https://doi.org/10.1007/s11528-018-0337-y

14. Knuth, M. (2016). D5.3 - Instruments technical description and development scheduling. TeSLA Adaptive Trust-Based e-Assessment System for Learning. Retrieved from https://teslaproject.eu/wp-content/uploads/2017/06/D5.3-Instruments-technical-description-anddevelopmenet-scheduling.pdf

15. Kunttu, K., Pesonen, T., \& Saari, J. (2017). Korkeakouluopiskelijoiden terveystutkimus 2016. [A National Survey of Finnish University Students 2016]. Helsinki: Finnish Student Health Service, Ylioppilaiden terveydenhoitosäätiön tutkimuksia 48. Retrieved from https://www.yths.fi/app/uploads/2020/01/KOTT_2016-1.pdf

16. Ladonlahti, T., Laamanen, M., \& Uotinen, S. (2020). Ensuring diverse user experiences and accessibility while developing the TeSLA e-assessment system. In D. Baneres, M.E. Rodríguez \& A.E. Guerrero-Roldán (Eds.), Engineering Data-Driven Adaptive Trust-Based e-Assessment Systems. Series title: Lecture Notes on Data Engineering and Communications Technologies 34 (pp. 213-238). Switzerland: Springer Nature. doi:10.10007/978-3-030-29326-0. Chapter's doi:10.10007/978-3-030-29326-0_10

17. Lee-Post, A., \& Hapke H. (2017). Online learning integrity approaches: current practices and future solution. Online Learning, 21(1), 135-145.

18. Levy, Y., Ramim, M. M., Furnell, S. M., \& Clarke, N. L. (2011). Comparing intentions to use university-provided vs vendor-provided multibiometric authentication in online exams. Campus-Wide Information System, 28(2), 102-113. Retrieved from https://www.emerald.com/insight/content/doi/10.1108/10650741111117806/full/html

19. Lombardi, A., Vukovic, B., \& Sala-Bars, I. (2015). International comparisons of inclusive instruction among college faculty in Spain, Canada, and the United States. Journal of Postsecondary Education and Disability, 28(4), 447-460. 
20. Macy, M., Macy, C., \& Shaw, M. E. (2018). Bringing the ivory tower into students' homes: promoting accessibility in online courses. Ubiquitous Learning: An International Journal, 1(1), 13-21. https://doi.org/10.18848/1835-9795/CGP/v11i01/13-21

21. Mellar, H., Peytcheva-Forsyth, R., Kocdar, S., Karadeniz, A., \& Yovkova. B. (2018). Addressing cheating in e-Assessment using student authentication and authorship checking systems: teachers' perspectives. International Journal for Educational Integrity, 14(2). doi:10.1007/s40979-018-0025-x

22. Okada, A., Noguera, I., Alexieva, L., Rozeva, A., Kocdar, S., Brouns, F., Ladonlahti, T., Whitelock, D., \& Guerrero-Roldán, A-E. (2019). Pedagogical approaches for e-assessment with authentication and authorship verification in Higher Education. British Journal of Educational Technology, 50(6), 3264-3282. doi:10.1111/bjet.12733

23. Okada, A., Whitelock, D., Holmes, W., \& Edwards C. (2019). E-authentication for online assessment: a mixed-method study. British Journal of Educational Technology, 15(2), 861-875. doi:10.1111/bjet.12608

24. Patton, M., Q. (2015). Qualitative research \& evaluation methods ( $4^{\text {th }}$ ed.). Thousand Oaks, CA: Sage.

25. Peytcheva-Forsyth, R., Blagovesna, Y., \& Ladonlahti, T. (2017). The potential of the TeSLA authentication system to support access to e-assessment for students with special educational needs and disabilities (Sofia University experience). Proceedings of ICERI2017 Conference 1618 November, Seville, Spain, 4593-4602.

26. Potila, A-K., Moisio, J., Ahti-Miettinen, O., Pyy-Martikainen, M., \& Virtanen, V. (2017). Opiskelijatutkimus 2017. EUROSTUDENT VI -tutkimuksen keskeiset tulokset. [Student survey 2017. Key results of Finnish Eurostudent VI survey]. Publications of the Ministry of Education and Culture 37. Retrieved from http://urn.fi/URN:ISBN:978-952-263-500-6

27. Snyder, T. D., Brey, C., \& Dillow, S. A. (2018). Digest of Education Statistics 2016 ( $52^{\text {nd }}$ ed.). NCES National Center for Education Statistics. Retrieved from https://nces.ed.gov/pubs2017/2017094.pdf

28. TeSLA. (2019). TeSLA Project. Retrieved from https://tesla-project.eu

29. Timmis, S., Bradfoot, P., Sutherland, R., \& Oldfield, A. (2016). Rethinking assessment in a digital age: opportunities, challenges and risks. British Educational Research Journal, 42(3), 452-476. doi:10.1002/berj.3215

30. Verdinelli, S., \& Kutner, D. (2016). Persistence factors among online graduate students with disabilities. Journal of Diversity in Higher Education, 9(4), 353-368. http://dx.doi.org/10.1037/a0039791

\section{Acknowledgement}

This work was supported by the European Commission H2020-ICT-2015/H2020-ICT-2015 TeSLAproject, “An Adaptive Trust-Based E-Assessment System for Learning” number 688520. 